\title{
Aplikasi Disinfektan dan 1-Methylcyclopropene untuk Mempertahankan Vase Life Bunga Potong Heliconia chartacea Lane ex Barreiros cv. 'Sexy Pink'
}

\author{
Application of Disinfectant and 1-Methylcyclopropene to Keep Vase Life of Cut \\ Flower Heliconia chartacea Lane ex Barreiros cv. 'Sexy Pink'
}

\author{
Juang G. Kartika ${ }^{1 *}$ dan Siti Rohmah ${ }^{2}$
}

Diterima 20 April 2016/Disetujui 08 Februari 2017

\begin{abstract}
Heliconia 'Sexy Pink' has beautiful bright pink colour and big size of bractea. The quality of Heliconia 'Sexy Pink' as tropical cut flower can be maintained with appropriate post-harvest treatments. One of the post-harvest technology that can be applied is the use of disinfectant and 1 Methylcyclopropene (1-MCP). The objective of the study was to prolong the vase life of Heliconia 'Sexy Pink' using disinfectant and 1-MCP, and to determine the optimum concentration of disinfectant (active compound: sodium hyphoclorite- $\mathrm{NaClO}$ ) and 1-MCP applied separately or in combination. This study used factorial randomized complete block design with two factors and ten replications. The first factor was concentration of disinfectant (NaClO) i.e 0\% (AO), 0.5\% (A1), $1.0 \%$ (A2) and 1.5\% (A3). The second factor was 1-MCP i.e 0 ppm (B0), 0.003 ppm (B1), 0.004 ppm (B2) and $0.005 \mathrm{ppm}$ (B3). The results showed that optimum 1-MCP concentration for maintaining the vase life of Heliconia 'Sexy Pink' cut flowers by $30 \%$ from total amount of bractea blackened variables was $0.005 \mathrm{ppm}$; This 1-MCP concentration kept the vase life for 6.2 days. Vase life of Heliconia 'Sexy Pink' cut flower with the combination treatment without disinfectant and 1-MCP concentration of 0-0.005 ppm based on hedonic test by panelists still preferably up to 8 days. Hedonic test criteria is recommended to indicate the vase life of Heliconia 'Sexy Pink' cut flower. The addition of the disinfectant is not advisable to maintain the vase life of Heliconia 'Sexy Pink' cut flower.
\end{abstract}

Key words: 1-methylcylopropen, Heliconia, $\mathrm{NaClO}$, tropical cut flower, vase life

\begin{abstract}
ABSTRAK
Heliconia 'Sexy Pink' memiliki warna merah muda yang indah dengan ukuran besar dan rangkaian braktea cukup banyak. Kualitas bunga Heliconia 'Sexy Pink' sebagai bunga potong tropis dapat dipertahankan kesegarannya dengan perlakuan aplikasi pascapanen yang tepat. Salah satu teknologi pasca panen yang dapat digunakan ialah aplikasi bahan kimia berupa disinfektan dan 1 Methylcyclopropene (1-MCP). Penelitian ini bertujuan mempertahankan vase life bunga potong Heliconia 'Sexy Pink' menggunakan disinfektan (bahan aktif: sodium hipoklorit-NaClO) dan 1MCP. Penelitian ini mengggunakan rancangan kelompok lengkap teracak (RKLT) faktorial dengan dua faktor. Faktor pertama adalah konsentrasi disinfektan (NaClO): $0 \%(\mathrm{~A} 0), 0.5 \%$ (A1), $1.0 \%(\mathrm{~A} 2)$ dan $1.5 \%$ (A3). Faktor kedua yaitu konsentrasi 1-MCP: 0 ppm (B0), 0.003 ppm (B1), 0.004 ppm (B2) dan 0.005 ppm (B3), sehingga terdapat 16 kombinasi perlakuan yang diulang 10 kali. Setiap satuan percobaan terdiri atas 1 tangkai bunga, sehingga terdapat 160 tangkai bunga Heliconia 'Sexy Pink'. Hasil penelitian menunjukkan bahwa konsentrasi 1-MCP yang optimum untuk mempertahankan vase life bunga potong Heliconia 'Sexy Pink' berdasarkan peubah $30 \%$ braktea menghitam adalah $0.005 \mathrm{ppm}$; konsentrasi ini dapat memperpanjang masa segar bunga selama 6.20 hari. Vase life bunga potong Heliconia 'Sexy Pink' dengan kombinasi perlakukan tanpa disinfektan
\end{abstract}


dan konsentrasi 1-MCP 0-0.005 ppm berdasarkan uji hedonik masih disukai panelis hingga 8 hari. Kriteria uji hedonik lebih direkomendasikan untuk menunjukkan vase life bunga potong Heliconia 'Sexy Pink'. Penambahan disinfektan tidak disarankan untuk mempertahankan vase life bunga potong Heliconia 'Sexy Pink'.

Kata kunci: 1-methylcylopropene, bunga tropis, Heliconia, $\mathrm{NaClO}$, vase life

\section{PENDAHULUAN}

Indonesia merupakan negara tropika yang memiliki potensi tinggi untuk mengembangkan berbagai jenis tanaman hias tropis. Jenis bunga potong tropis yang dikembangkan di Indonesia antara lain berasal dari famili Zingiberaceae, Costaceae, dan Heliconiaceae. Salah satu anggota famili Heliconiaceae yang banyak digunakan sebagai bunga potong tropis adalah spesies Heliconia chartacea Lane ex Barreiros cv. 'Sexy Pink'. Bunga potong Heliconiaceae sangat terkenal karena sifatnya yang eksotis dan pasca panennya yang mampu bertahan lama (Pereira et al., 2015).

Heliconia 'Sexy Pink' merupakan tanaman herba tahunan, merumpun, berbatang semu, berdaun panjang dan lebar. Braktea Heliconia 'Sexy Pink' secara spesifik memiliki warna merah muda. Heliconia jenis ini memiliki panjang tangkai bunga sekitar 120 $\mathrm{cm}$. Ukuran braktea bunga dibedakan menjadi kelas kecil, sedang, dan besar (Bigot, 2011). Menurut Rimando (2001), jumlah braktea pada bunga Heliconia 'Sexy Pink' dapat mencapai 28 braktea.

Aplikasi perlakuan pascapanen yang tepat sangat diperlukan untuk menjaga kesegaran bunga dan mempertahankan vase life bunga potong. Tanpa perlakuan atau aplikasi teknik pascapanen yang tepat kehilangan produksi bunga akibat bunga layu dan faktor lainnya dapat mencapai 30\% sampai dengan 60\% (Astuti, 1993). Penanganan yang perlu dilakukan antara lain dengan cara perendaman dalam larutan pengawet yang dapat memperlambat proses kerusakannya. Heliconia 'Sexy Pink' dapat dipertahankan keindahannya dalam waktu satu hingga dua minggu dengan perawatan atau perlakuan yang baik (Bigot, 2011), sedangkan menurut penjual bunga potong Heliconia 'Sexy Pink' di Pasar Rawa Belong, bunga potong tersebut hanya mampu bertahan empat hingga enam hari saja (komunikasi pribadi).
Perlu dilakukan penanganan pascapanen yang tepat agar produk tetap segar dan berkualitas sampai ke tangan konsumen.

Teknologi pascapanen yang kini sudah mulai diterapkan di beberapa negara salah satunya adalah penggunaan bahan kimia sebagai bahan pengawet berupa 1Methylcyclopropene (1-MCP) dan penggunaan disinfektan sebagai antibakteri. 1-MCP merupakan senyawa yang mampu mereduksi etilen (Reid and Çelikel, 2008). Bahan kimia ini digunakan pada tanaman hortikultura seperti buah dan sayur (Watkins, 2008). Pengaplikasian 1-MCP dapat menghambat produksi etilen secara kimiawi dengan menonaktifkan reseptor etilen (Efendi, 2005). Kemampuan 1-MCP untuk berikatan dengan reseptor 10 kali lebih besar dibanding etilen. Di sisi lain 1-MCP dapat aktif pada konsentrasi rendah. Mubarok (2012) mengungkapkan bahwa penggunaan 1-MCP pada konsentrasi rendah $0.25 \mu \mathrm{L} \mathrm{L}^{-1}$ sudah mampu mempertahankan kualitas bunga krisan potong 'Yellow Fiji' dengan cara menghambat terjadinya perubahan warna bunga, mencegah pelayuan bunga dan memperpanjang lama kesegaran bunga. Kartika dan Adyantari (2014) menyatakan bahwa perlakuan 1-MCP konsentrasi $0.004 \mathrm{ppm}$ dengan cara aplikasi direndam dapat memperpanjang vase life bunga bihip (Zingiber spectabile Griff. Silvana).

Bayclin atau sejenis bahan pemutih pakaian sering digunakan untuk memperpanjang kesegaran bunga potong. Macnish et al., (2010) melaporkan bahwa larutan sodium hipoklorit efektif mereduksi serangan fungi pada bunga mawar. Lingga (2007) mengungkapkan bahwa bahan aktif Bayclin (sodium hipoklorit-NaClO) dengan konsentrasi $1 \%$ dapat digunakan untuk merendam tangkai bunga anthurium setelah tangkai dipotong untuk menghindari infeksi penyakit. Penelitian untuk membuktikan hal tersebut penting untuk dilakukan, dengan mengkombinasikan penggunaan 1-MCP dan disinfektan pada konsentrasi yang berbeda 
untuk mempertahankan vase life bunga potong Heliconia 'Sexy Pink'selama penyimpanan.

Penelitian ini bertujuan mempertahankan vase life bunga potong Heliconia 'Sexy Pink' menggunakan disinfektan $(\mathrm{NaClO})$ dan 1MCP, dan mendapatkan kombinasi perlakuan disinfektan dan atau 1-MCP yang efektif memperpanjang vase life bunga potong Heliconia 'Sexy Pink'.

\section{METODE PENELITIAN}

Penelitian dilaksanakan di Laboratorium Pascapanen Departemen Agronomi dan Hortikultura Institut Pertanian Bogor. Penelitian dimulai pada bulan Desember 2014 sampai Januari 2015.

Percobaan menggunakan rancangan kelompok lengkap teracak (RKLT) faktorial dengan 2 faktor, masing-masing faktor terdiri atas 4 taraf, yaitu faktor konsentrasi disinfektan $(\mathrm{NaClO}) 0 \%, 0.5 \%, 1.0 \%$, dan $1.5 \%$, dan konsentrasi 1-MCP 0 ppm, 0.003 ppm, 0.004 ppm, dan 0.005 ppm. Kombinasi perlakuan yang terdapat pada penelitian ini yaitu sebanyak 16 kombinasi perlakuan. Setiap perlakuan diulang 10 kali dengan masingmasing ulangan terdiri atas 1 tangkai bunga, sehingga penelitian ini memerlukan 160 tangkai bunga potong Heliconia 'Sexy Pink' Data dianalisis sidik ragam dengan $\alpha=5 \%$, jika perlakuan menunjukkan pengaruh yang nyata terhadap peubah yang diamati, maka dilakukan analisis uji beda nilai tengah dengan uji lanjut Duncan Multiple Range Test (DMRT).

Bunga potong Heliconia 'Sexy Pink' dipanen dari kebun petani di Cicurug, Sukabumi. Pemanenan bunga dilakukan dengan cara memotong pangkal tangkai bunga menggunakan golok saat minimal 5 helai braktea telah terbuka. Kriteria yang digunakan dalam memilih bunga potong Heliconia 'Sexy Pink' yang digunakan untuk percobaan meliputi warna braktea merah muda dan tidak pucat. Jumlah braktea terbuka berkisar antara 5-12 braktea per tangkai dengan kondisi segar dan tidak patah. Panjang tangkai bunga 125 $\mathrm{cm}$ diukur dari pangkal tangkai sampai ujung tangkai braktea.

Bunga Heliconia 'Sexy Pink' yang telah dipanen diangkut ke Laboratorium Pascapanen Departemen Agronomi dan Hortikultura IPB (lokasi penelitian) dengan menggunakan mobil bak terbuka. Bunga ditutup dengan paranet agar tidak terkena sinar matahari langsung. Penyortiran bunga dilakukan sebelum aplikasi perlakuan berdasarkan kondisi braktea, jumlah braktea dan panjang tangkai.

Pembuatan larutan disinfektan dan 1MCP untuk aplikasi perlakuan sesuai dengan konsentrasi yang telah ditentukan. Perlakuan aplikasi disinfektan dan 1-MCP yaitu dengan cara merendam seluruh bagian bunga potong selama 5 menit. Wadah yang digunakan untuk perendaman bunga potong adalah kain terpal yang dibentuk seperti kolam, dengan menggunakan penyangga untuk memperkuat bagian dindingnya. Setelah dilakukan perendaman, bunga potong disimpan dalam ember yang telah diisi air dan $15 \%$ gula. Tangkai bunga dipotong sepanjang $3 \mathrm{~cm}$ setiap 3 hari sekali untuk mencegah terjadinya embolism. Pengamatan dilakukan sebelum dan sesudah perlakuan disinfektan dan 1-MCP. Selanjutnya, diamati setiap hari sampai vase life bunga berakhir kecuali pengamatan uji hedonik yang dilakukan setiap 2 hari sekali.

Peubah-peubah yang diamati yaitu: warna tangkai, warna braktea, jumlah braktea menghitam, susut bobot, uji hedonik, dan vase life. Pengamatan warna braktea dan warna tangkai bunga dilakukan secara visual menggunakan bagan warna (mini colour chart) yang dikeluarkan oleh Royal Horticulture Society (RHS). Jumlah braktea yang menghitam diamati dengan cara menghitung jumlah braktea yang menghitam setiap hari selama penyimpanan. Satu braktea dikatakan menghitam apabila $30 \%$ dari luas braktea tersebut berwarna hitam. Vaselife bunga potong dikatakan berakhir jika 30\% dari jumlah total braktea telah menghitam. Susut bobot diukur dengan membandingkan antara bobot awal dengan bobot akhir dari bunga potong saat pengamatan.

\section{HASIL DAN PEMBAHASAN}

Bunga potong Heliconia 'Sexy Pink' yang telah dipanen segera dibawa dari Sukabumi (lokasi kebun) ke Laboratorium Pascapanen, Departemen Agronomi dan Hortikultura, IPB. Penyimpanan bunga potong yaitu di ruang Laboratorium Pascapanen dengan suhu rata-rata $27{ }^{\circ} \mathrm{C}$ dan kelembaban rata-rata $90 \%$. Pengaplikasian disinfektan 
( $\mathrm{NaClO})$ dan 1-MCP terhadap Bunga potong Heliconia 'Sexy Pink' pada penelitian ini dilakukan 25 jam atau satu hari setelah pemanenan.

Berdasarkan kriteria Bigot (2011), bunga Heliconia 'Sexy Pink' dibedakan menjadi tiga kelas. Ukuran kecil memiliki bunga berukuran $15 \mathrm{~cm}$ dan batang $80 \mathrm{~cm}$, untuk ukuran medium panjang batang mencapai $70 \mathrm{~cm}$ hingga $90 \mathrm{~cm}$, panjang bunga $20 \mathrm{~cm}$ dan memiliki 3 sampai 4 braktea. Ukuran besar memiliki panjang batang mencapai $110 \mathrm{~cm}$ dengan lebih dari 5 braktea. Berdasarkan panjang batang dan jumlah braktea menurut Bigot (2011), bunga potong Heliconia 'Sexy Pink' yang digunakan dalam percobaan ini termasuk kelas besar.

\section{Warna Tangkai}

Warna tangkai pada bunga potong 'Sexy Pink'Heliconia 'Sexy Pink'merupakan salah satu ukuran kesegaran secara visual. Pengukuran warna tangkai pada bunga potong Heliconia 'Sexy Pink' menggunakan bagan warna (mini colour chart) dari RHS. Warna tangkai bunga Heliconia 'Sexy Pink' berubah dari hijau (green) menjadi hijau tua (dark green) selama pengamatan. Tangkai bunga potong Heliconia 'Sexy Pink' memiliki warna hijau RHS $137 \mathrm{C}$ pada 0 hari setelah perlakuan (HSP) hingga 1 HSP yang menunjukkan bahwa tangkai bunga masih segar. Menurut Qiuping dan Wenshui (2007), perlakuan 1MCP mampu mempertahankan klorofil buah jujube india hingga 12 pada hari masa penyimpanan. Warna tangkai bunga potong Heliconia 'Sexy Pink' menjadi hijau tua RHS 137A pada 2 HSP hingga 4 HSP yang menunjukkan bahwa warna tangkai sudah mulai gelap. Warna tangkai bunga potong Heliconia 'Sexy Pink' pada 5 HSP dan 6 HSP menjadi hijau tua RHS $141 \mathrm{C}$ dan pada 7 HSP hingga 9 HSP menjadi hijau tua RHS 144A. Kedua warna tersebut menunjukkan bahwa tangkai bunga semakin gelap dan layu.

Perubahan warna tangkai dijadikan sebagai salah satu kriteria dalam penampilan bunga. Degradasi pigmen warna merupakan gejala umum senesen beberapa bunga potong. Menurut Bhattarchajee dan De (2005), respirasi dan transpirasi menyebabkan terjadinya senesen serta berkurangnya kandungan karbohidrat pada daun dan tangkai.
Selama periode senesen terjadi penurunan kandungan amilum atau tepung, polisakarida dinding sel, protein dan asam nukleat. Penurunan kandungan gula akan diikuti pengurangan kandungan lemak dan protein pada jaringan.

\section{Warna Braktea}

Warna braktea tidak mengalami perubahan yang signifikan selama masa penyimpanan. Pergeseran warna terjadi dari warna merah muda gelap kemerahan (Dark pink red) menjadi merah muda kemerahan (red pink). Warna braktea dari hasil penelitian ini dapat dibagi ke dalam 3 bagian, yaitu pangkal, tengah dan ujung (kuncup) braktea. Umumnya braktea berwarna merah muda gelap kemerahan RHS 51B (80-90\% dari permukaan braktea). Warna tersebut menunjukkan bahwa braktea bunga masih segar. Bagian pangkal susunan bunga kurang dari 5\% berwarna merah pink kemerahan RHS 50B yang menunjukkan bahwa warna lebih gelap karena braktea tersebut merupakan braktea yang pertama muncul. Bagian kuncup bunga berkisar antara $5-10 \%$ berwarna merah muda kemerahan RHS 48C dan RHS 49A yang menunjukkan bahwa braktea tersebut baru mekar sehingga warnanya lebih pudar dan pucat, hal ini diduga karena pigmen warna pada braktea yang baru mekar belum terbentuk sempurna. Semakin lama braktea tersebut mekar, maka warna merah muda menjadi semakin kuat.

\section{Persentase Jumlah Braktea Menghitam}

Braktea mulai menghitam pada satu HSP. Semburat hitam mulai muncul dari tepi ke bagian dalam braktea. Semakin banyak semburat hitam pada braktea maka penampilannya semakin tidak menarik. Begitu juga dengan vase life, semakin cepat waktu munculnya semburat hitam pada braktea maka semakin pendek vase life bunga potongnya. Menurut Setyadjit et al. (2012) pengaruh etilen pada tanaman hias seperti terjadinya gugur pada daun, kuncup bunga, kelopak bunga, atau secara umum terjadi pada daerah sambungan tanaman (abscission zone). Penggunaan larutan pengawet mampu mempertahankan masa kesegaran bunga potong (Amiarsi dan Utami, 2011). 
Data pada Tabel 1 menunjukkan adanya interaksi yang sangat nyata antara konsentrasi disinfektan dengan konsentrasi 1-MCP pada 2 HSP dan berpengaruh nyata pada 4 HSP terhadap persentase jumlah braktea menghitam. Hal tersebut dapat dilihat pada (Tabel 2) yang menunjukkan bahwa konsentrasi $1.0 \%$ disinfektan yang ditambah 0.004 ppm 1-MCP memiliki persentase jumlah braktea menghitam yaitu $25.1 \%$ sedangkan pada 4 HSP pengaruh interaksi disinfektan dan 1-MCP menunjukkan bahwa 0\% disinfektan yang ditambah 0 ppm 1-MCP tidak berbeda nyata dengan interaksi antara $0.5 \%$ disinfektan yang ditambah dengan $0.003 \mathrm{ppm}, 0.004 \mathrm{ppm}$ dan $0.005 \mathrm{ppm} 1$-MCP serta tidak berbeda nyata dengan interaksi antara $1.5 \%$ disinfektan yang di tambah dengan $0.005 \mathrm{ppm} 1-\mathrm{MCP}$. Hal ini menunjukkan bahwa pemberian disinfektan dengan konsentrasi rendah ditambah dengan berbagai konsentrasi 1-MCP menghasilkan persentase jumlah braktea menghitam yang lebih rendah. Pengamatan persentase braktea menghitam hanya dilakukan hingga maksimal $30 \%$ dari total braktea telah menghitam, karena merujuk pada kriteria vase life Zingiberaceae dari Ditflorikultura (2006) yaitu vase life dinyatakan berakhir setelah $30 \%$ dari jumlah total brakteanya menghitam.

Perlakuan konsentrasi disinfektan berpengaruh sangat nyata pada 2 HSP, 3 HSP dan 4 HSP (Tabel 1). Perlakuan dengan konsentrasi disinfektan secara tunggal menghasilkan persentase jumlah braktea menghitam paling tinggi. Bunga potong yang diberi perlakuan disinfektan hanya memiliki vase life 4 HSP hingga 5 HSP kecuali pada konsentrasi $0 \%$ yang mencapai 9 HSP. Semakin tinggi konsetrasi disinfektan yang diberikan, jumlah braktea menghitam semakin banyak dan semakin pendek vase life bunga potong Heliconia 'Sexy Pink'.

Perlakuan konsentrasi 1-MCP tidak menghasilkan pengaruh yang nyata terhadap jumlah braktea menghitam Bunga potong yang diberi perlakuan 1-MCP memiliki vase life 8 HSP hingga 9 HSP. Hal tersebut menunjukkan bahwa penggunaan 1-MCP menghasilkan penambahan braktea menghitam lebih lambat. Hasil penelitian Kartika dan Salsabila (2013) menunjukkan bahwa bunga potong kasturi (Tapeinochilos anannaceae K. Schum) yang diberi perlakuan 1-MCP menghasilkan waktu menghitamnya braktea lebih lambat dibandingkan dengan yang tidak diberi perlakuan 1-MCP.

Tabel 1. Persentase jumlah braktea menghitam pada berbagai konsentrasi disinfektan dan 1-MCP

\begin{tabular}{|c|c|c|c|c|c|c|c|c|c|}
\hline \multirow{2}{*}{ Perlakuan } & \multicolumn{9}{|c|}{ Umur Bunga (HSP) } \\
\hline & 1 & 2 & 3 & 4 & 5 & 6 & 7 & 8 & 9 \\
\hline \multicolumn{10}{|c|}{ Braktea Menghitam (\%) } \\
\hline \multicolumn{10}{|c|}{ Konsentrasi disinfektan (\%) } \\
\hline 0 & 1.9 & $4.6 \mathrm{~b}$ & $8.1 \mathrm{~b}$ & $15.0 \mathrm{~b}$ & 21.4 & 24.2 & 26.7 & 27.9 & 33.0 \\
\hline 0.5 & 3.9 & $3.4 \mathrm{~b}$ & $11.8 \mathrm{~b}$ & $25.3 \mathrm{ab}$ & 28.6 & - & - & - & - \\
\hline 1.0 & 3.1 & $12.4 \mathrm{a}$ & $28.3 \mathrm{a}$ & $28.1 \mathrm{a}$ & 30.0 & - & - & - & - \\
\hline 1.5 & 6.6 & $10.9 \mathrm{a}$ & $28.3 \mathrm{a}$ & $30.0 \mathrm{a}$ & - & - & - & - & - \\
\hline Anova & tn & $* *$ & $* *$ & $* *$ & tn & tn & tn & tn & tn \\
\hline \multicolumn{10}{|c|}{ Konsentrasi 1-MCP (ppm) } \\
\hline 0 & 3.7 & 5.7 & 17.9 & 21.4 & 25.6 & 26.9 & 27.0 & 27.0 & 30.0 \\
\hline 0.003 & 4.3 & 7.8 & 17.8 & 20.0 & 20.5 & 23.7 & 27.5 & 30.0 & - \\
\hline 0.004 & 3.8 & 9.5 & 17.8 & 21.9 & 26.2 & 27.0 & 28.0 & 30.0 & - \\
\hline 0.005 & 3.6 & 7.9 & 15.9 & 19.0 & 19.6 & 24.7 & 25.6 & 26.8 & 34.4 \\
\hline Anova & $\operatorname{tn}$ & $\operatorname{tn}$ & tn & tn & tn & tn & tn & tn & tn \\
\hline Interaksi & tn & $* *$ & tn & $*$ & $\operatorname{tn}$ & tn & tn & tn & tn \\
\hline
\end{tabular}


Tabel 2. Interaksi antara persentase jumlah braktea menghitam pada kombinasi perlakuan disinfektan dan 1-MCP

\begin{tabular}{ccc}
\hline \multicolumn{2}{c}{ Perlakuan } & \multicolumn{2}{c}{ Umur Bunga (HSP) } \\
\cline { 2 - 3 } $0 \% \mathrm{~A}+0 \quad \mathrm{ppm} \mathrm{B}$ & \multicolumn{2}{c}{ Jumlah Braktea Menghitam $(\%)$} \\
$0 \% \mathrm{~A}+0.003 \mathrm{ppm} \mathrm{B}$ & $11.8 \mathrm{a}$ & $21.5 \mathrm{abc}$ \\
$0 \% \mathrm{~A}+0.004 \mathrm{ppm} \mathrm{B}$ & $0.9 \mathrm{a}$ & $12.0 \mathrm{ab}$ \\
$0 \% \mathrm{~A}+0.005 \mathrm{ppm} \mathrm{B}$ & $3.9 \mathrm{a}$ & $15.9 \mathrm{ab}$ \\
$0.5 \% \mathrm{~A}+0.000 \mathrm{ppm} \mathrm{B}$ & $1.7 \mathrm{a}$ & $10.5 \mathrm{a}$ \\
$0.5 \% \mathrm{~A}+0.003 \mathrm{ppm} \mathrm{B}$ & $2.2 \mathrm{a}$ & $18.7 \mathrm{ab}$ \\
$0.5 \% \mathrm{~A}+0.004 \mathrm{ppm} \mathrm{B}$ & $4.9 \mathrm{a}$ & $26.7 \mathrm{abc}$ \\
$0.5 \% \mathrm{~A}+0.005 \mathrm{ppm} \mathrm{B}$ & $2.0 \mathrm{a}$ & $29.2 \mathrm{bc}$ \\
$1.0 \% \mathrm{~A}+0$ & $\mathrm{ppm} \mathrm{B}$ & $27.1 \mathrm{bc}$ \\
$1.0 \% \mathrm{~A}+0.003 \mathrm{ppm} \mathrm{B}$ & $2.0 \mathrm{a}$ & $27.4 \mathrm{bc}$ \\
$1.0 \% \mathrm{~A}+0.004 \mathrm{ppm} \mathrm{B}$ & $13.6 \mathrm{a}$ & - \\
$1.0 \% \mathrm{~A}+0.005 \mathrm{ppm} \mathrm{B}$ & $25.1 \mathrm{~b}$ & - \\
$1.5 \% \mathrm{~A}+0 \quad \mathrm{ppm} \mathrm{B}$ & $10.3 \mathrm{a}$ & - \\
$1.5 \% \mathrm{~A}+0.003 \mathrm{ppm} \mathrm{B}$ & $6.4 \mathrm{a}$ & - \\
$1.5 \% \mathrm{~A}+0.004 \mathrm{ppm} \mathrm{B}$ & $12.3 \mathrm{a}$ & - \\
$1.5 \% \mathrm{~A}+0.005 \mathrm{ppm} \mathrm{B}$ & $8.2 \mathrm{a}$ & $30.0 \mathrm{c}$ \\
\hline
\end{tabular}

Keterangan: Angka-angka yang diikuti huruf yang sama pada kolom yang sama menunjukkan hasil yang tidak berbeda nyata berdasarkan uji lanjut DMRT pada taraf $\alpha=5 \%$; A: disinfektan; B: 1-MCP; - : pengamatan tidak dilakukan karena kriteria vase life telah terlewati.

\section{Susut Bobot}

Bunga potong Heliconia 'Sexy Pink' mengalami susut bobot selama pengamatan berlangsung. Penurunan bobot dapat disebabkan oleh respirasi dan transpirasi pada daun dan tangkai bunga. Selama pengamatan susut bobot terjadi proses respirasi dan transpirasi, juga terjadi karena gugurnya bunga biologis yang terdapat didalam braktea serta terdapat beberapa braktea yang patah karena layu atau gugur bunga akibat pengaruh etilen. Menurut Santoso (2012) bunga potong akan mengalami kehilangan air secara terus menerus seiring dengan berjalannya waktu setelah panen khususnya pada saat penyimpanan.

Persentase susut bobot bunga potong Heliconia 'Sexy Pink' secara umum semakin meningkat (Tabel 3). Semakin lama vase life bunga potong maka susut bobotnya semakin tinggi. Pengaplikasian disinfektan dan 1-MCP hingga 9 HSP mencapai 27\%. Presentase susut bobot tidak berbeda nyata pada semua kombinasi perlakuan interaksi. Presentase susut bobot hanya dipengaruhi oleh faktor tunggal yaitu konsentrasi disinfektan pada 2 HSP dan berpengaruh sangat nyata pada faktor tunggal yaitu konsentrasi 1MCP pada 1 HSP. Perlakuan tanpa 1-MCP (1MCP $0 \mathrm{ppm}$ ) menghasilkan persentase susut bobot tertinggi pada 1 HSP yaitu sebesar 5.06\% dibandingkan dengan perlakuan menggunakan 1MCP lainnya. Kartika dan Adyantari (2014) mengungkapkan bahwa bunga bihip yang tidak diberi perlakuan 1-MCP mengalami peningkatan persentase susut bobot yang lebih besar dibandingkan dengan bunga bihip yang diberi perlakuan 1-MCP.

Peubah susut bobot tidak terlalu dipengaruhi oleh perlakuan dalam penelitian ini karena hampir semua bunga potong Heliconia 'Sexy Pink'mengalami penurunan susut bobot yang sama setiap hari untuk semua kombinasi perlakuan. Kesegaran bunga potong tidak dilihat dari susut bobotnya saja sehingga pengukuran vase life juga harus berdasarkan peubah lainnya yang dapat dilihat secara visual. 
Tabel 3. Persentase susut bobot bunga potong Heliconia 'Sexy Pink' pada berbagai konsentrasi disinfektan dan 1-MCP

\begin{tabular}{|c|c|c|c|c|c|c|c|c|c|}
\hline \multirow{2}{*}{ Perlakuan } & \multicolumn{9}{|c|}{ Umur Bunga (HSP) } \\
\hline & 1 & 2 & 3 & 4 & 5 & 6 & 7 & 8 & 9 \\
\hline \multicolumn{10}{|c|}{ Susut Bobot (\%) } \\
\hline \multicolumn{10}{|c|}{ Konsentrasi disinfektan (\%) } \\
\hline 0 & $2.7 \mathrm{a}$ & $8.2 \mathrm{ab}$ & $10.2 \mathrm{a}$ & $13.7 \mathrm{a}$ & $16.8 \mathrm{a}$ & $17.8 \mathrm{a}$ & 19.8 & 23.8 & 27.6 \\
\hline 0.5 & $2.6 \mathrm{a}$ & $6.8 \mathrm{~b}$ & $10.1 \mathrm{a}$ & $12.9 \mathrm{a}$ & $14.1 \mathrm{a}$ & $17.7 \mathrm{a}$ & - & - & - \\
\hline 1.0 & $4.9 \mathrm{a}$ & $10.1 \mathrm{a}$ & $11.0 \mathrm{a}$ & $13.8 \mathrm{a}$ & $13.9 \mathrm{a}$ & - & - & - & - \\
\hline 1.5 & $2.9 \mathrm{a}$ & $7.3 \mathrm{~b}$ & $9.2 \mathrm{a}$ & $12.7 \mathrm{a}$ & - & - & - & - & - \\
\hline Anova & $\operatorname{tn}$ & $*$ & tn & $\operatorname{tn}$ & $\operatorname{tn}$ & $\operatorname{tn}$ & tn & tn & tn \\
\hline \multicolumn{10}{|c|}{ Konsentrasi 1-MCP (ppm) } \\
\hline 0 & $5.1 \mathrm{a}$ & $9.1 \mathrm{a}$ & $11.1 \mathrm{a}$ & $14.4 \mathrm{a}$ & $16.7 \mathrm{a}$ & $18.0 \mathrm{a}$ & $20.6 \mathrm{a}$ & 23.0 & 27.9 \\
\hline 0.003 & $2.6 \mathrm{~b}$ & $7.6 \mathrm{a}$ & $9.7 \mathrm{a}$ & $12.2 \mathrm{a}$ & $12.5 \mathrm{a}$ & $17.6 \mathrm{a}$ & $20.0 \mathrm{a}$ & 20.0 & - \\
\hline 0.004 & $1.6 \mathrm{~b}$ & $8.6 \mathrm{a}$ & $10.2 \mathrm{a}$ & $14.0 \mathrm{a}$ & $18.2 \mathrm{a}$ & $18.3 \mathrm{a}$ & $19.8 \mathrm{a}$ & 22.7 & - \\
\hline 0.005 & $3.2 \mathrm{~b}$ & $7.2 \mathrm{a}$ & $9.5 \mathrm{a}$ & $12.3 \mathrm{a}$ & $16.4 \mathrm{a}$ & $17.7 \mathrm{a}$ & $19.5 \mathrm{a}$ & 25.7 & 27.4 \\
\hline Anova & $* *$ & tn & $\operatorname{tn}$ & tn & tn & tn & tn & tn & tn \\
\hline Interaksi & tn & tn & tn & $\operatorname{tn}$ & tn & tn & tn & tn & tn \\
\hline
\end{tabular}

\section{Vase Life}

Vase life bunga potong merupakan lamanya umur relatif bunga potong dalam keadaan tetap segar dan indah setelah dipotong dari tanaman induknya (Wiryanto, 1993). Kriteria untuk menentukan lamanya vase life bunga potong Heliconia 'Sexy Pink' merujuk pada kriteria vase life Zingiberaceae dari Ditflorikultura (2006) yaitu vase life dinyatakan berakhir setelah $30 \%$ dari jumlah total brakteanya menghitam. Heliconia 'Sexy Pink' sebagai bunga potong tropis yang keindahannya dilihat dari brakteanya diasumsikan sama untuk menentukan vase life. Pengamatan dilakukan dari sebelum perlakuan (0 HSP) hingga vase life bunga potong berakhir.

Data pada Tabel 4 menunjukkan bahwa interaksi antara konsentrasi disinfektan dan 1MCP tidak berpengaruh nyata terhadap vase life bunga potong Heliconia 'Sexy Pink'. Faktor tunggal 1-MCP juga tidak berpengaruh nyata terhadap vase life bunga potong Heliconia 'Sexy Pink'. Faktor tunggal disiinfektan sangat berpengaruh nyata terhadap vase life bunga potong Heliconia 'Sexy Pink'. Hal ini terjadi karena konsentrasi disinfektan yang diaplikasikan terlalu tinggi sehingga menyebabkan braktea mengalami semburat hitam yang lebih banyak. Penelitian Macnish et al. (2008) menyatakan bahwa disinfektan sodium hypochlorite $(\mathrm{NaClO})$ pada konsentrasi $0.005 \%$ dapat memperpanjang vase life bunga
Gerbera 'Julia', 'Lorca' dan 'Vilassar'.

Vase life bunga potong Heliconia 'Sexy Pink' menurut Bigot (2011) adalah dua minggu dengan perlakuan pascapanen yang baik. Menurut pedagang bunga potong Heliconia 'Sexy Pink'di pasar Rawa Belong (komunikasi pribadi), bunga ini hanya bertahan empat hingga enam hari. Adanya perbedaan tersebut karena pascapanen di pasar Rawa Belong hanya dilakukan dengan penyiraman air yang dilakukan secara manual dan lingkungan penyimpanan yang kurang optimum seperti suhu dan kelembaban yang berfluktuasi.

Vase life bunga potong Heliconia 'Sexy Pink' secara visual dapat dibedakan berdasarkan perlakuan dengan konsentrasi disinfektan paling rendah dan konsentrasi disinfektan paling tinggi. Perlakuan 0\% disinfektan yang ditambah dengan $0.005 \mathrm{ppm}$ 1-MCP memiliki vase life paling lama dibandingkan dengan konsentrasi $0 \%$ disinfektan yang ditambah dengan $0.005 \mathrm{ppm}$ 1-MCP. Penelitian Zencirkiran (2010), menyatakan bahwa perlakuan 1-MCP pada konsentrasi $0.004 \mathrm{ppm}$ menghasilkan spike terpanjang dengan masa penyimpanan 9.06 hari pada bunga Freesia. Larutan 1-MCP dapat menghambat biosintesis dan pengikatan etilen ke reseptor sehingga vase life bunga potong anyelir mencapai 15.49 hari pada konsentrasi 0.06 ppm (Abadi et al., 2009). 
Tabel 4. Pengaruh aplikasi disinfektan dan 1-MCP terhadap vase life bunga potong Heliconia 'Sexy Pink'

\begin{tabular}{cc}
\hline Perlakuan & Vase Life (HSP) \\
\hline Konsentrasi disinfektan (\%) & $5.5 \mathrm{a}$ \\
0 & $4.1 \mathrm{~b}$ \\
0.5 & $2.8 \mathrm{c}$ \\
1.0 & $2.5 \mathrm{c}$ \\
\hline Anova & $* *$ \\
\hline Konsentrasi 1-MCP $(\mathrm{ppm})$ & $3.8 \mathrm{a}$ \\
0.003 & $3.8 \mathrm{a}$ \\
0.004 & $3.5 \mathrm{a}$ \\
0.005 & $3.8 \mathrm{a}$ \\
\hline Anova & tn \\
Interaksi & tn \\
\hline Keterangan: Angka-angka yang diikuti huruf yang sama pada kolom yang sama menunjukkan hasil yang tiak \\
berbeda nyata berdasarkan uji lanjut DMRT pada taraf $\alpha=5 \%$.
\end{tabular}

Data pada Gambar 1 menunjukkan bahwa bunga potong Heliconia 'Sexy Pink' yang diberi perlakuan $0 \%$ disinfektan dengan ditambahkan beberapa konsentrasi 1-MCP memiliki vase life yang lebih lama dibandingkan dengan perlakuan yang lain. Vase life terendah dengan konsentrasi $0 \%$ disinfektan adalah 4.80 hari tanpa penambahan konsentrasi 1-MCP. Vase life tertinggi adalah perlakuan $0 \%$ disinfektan yang ditambahkan dengan konsentrasi 0.005 ppm 1-MCP yaitu sebesar 6.20 hari. Vase life bunga potong dalam penelitian ini sangat dipengaruhi oleh disinfektan, semakin tinggi konsentrasi disinfektan yang diberikan maka vase life semakin rendah. Penambahan disinfektan tidak disarankan untuk mempertahankan vase life bunga potong Heliconia 'Sexy Pink', diduga karena konsentrasi yang diaplikasikan pada percobaan terlalu tinggi atau bunga potong Heliconia 'Sexy Pink' sensitif terhadap aplikasi bahan aktif disinfektan.

\section{Uji Hedonik}

Uji hedonik adalah uji kesukaan dilakukan oleh panelis tidak terlatih selama vase life bunga potong Heliconia 'Sexy Pink' belum berakhir. Penilaian yang dilakukan untuk uji hedonik berdasarkan penampilan bunga potong Heliconia 'Sexy Pink'secara visual. Uji hedonik dalam penelitian ini dilakukan oleh 10 orang panelis setiap dua hari sekali. Apabila nilai uji hedonik di atas sama dengan 3 maka bunga potong Heliconia 'Sexy Pink'masih dapat diterima oleh konsumen dan apabila nilai uji hedonik dibawah 3 berarti sudah tidak dapat diterima lagi oleh konsumen. Uji hedonik berhenti apabila vase life bunga potong berakhir.

Panelis menyukai penampilan bunga potong Heliconia 'Sexy Pink' sebelum diberi perlakuan yaitu dengan memberi nilai rata-rata 4 kecuali konsentrasi $0 \%$ disinfektan yang masing-masing ditambahkan konsentrasi 0.003 ppm, $0.004 \mathrm{ppm}$ dan $0.005 \mathrm{ppm} 1$-MCP. Panelis masih menyukai bunga potong Heliconia 'Sexy Pink' dari 2 HSP hingga 8 HSP untuk perlakuan konsentrasi $0 \%$ disinfektan terbukti dengan pemberian nilai 3 dari panelis hingga 8 HSP. Vase life pada perlakuan $0 \%$ disinfektan sebenarnya berakhir pada 9 HSP namun uji hedonik berhenti pada 8 HSP karena uji hedonik hanya dilakukan dua hari sekali. Perlakuan dengan konsentrasi disinfektan yang tinggi menyebabkan penampilan bunga sudah tidak menarik dengan adanya braktea menghitam dan warna tangkai yang semakin gelap sehingga panelis memberi nilai rendah untuk uji hedoniknya. Hal tersebut dibuktikan dengan pemberian nilai uji hedonik oleh panelis pada bunga hasil perlakuan konsentrasi $1.5 \%$ disinfektan ditambah berbagai konsentrasi 1-MCP hanya mampu bertahan hingga 2.5 HSP. Sama halnya dengan perlakuan konsentrasi $1.0 \%$ disinfektan pada berbagai konsentrasi 1-MCP yang hanya bertahan 2.8 HSP (Tabel 5). 


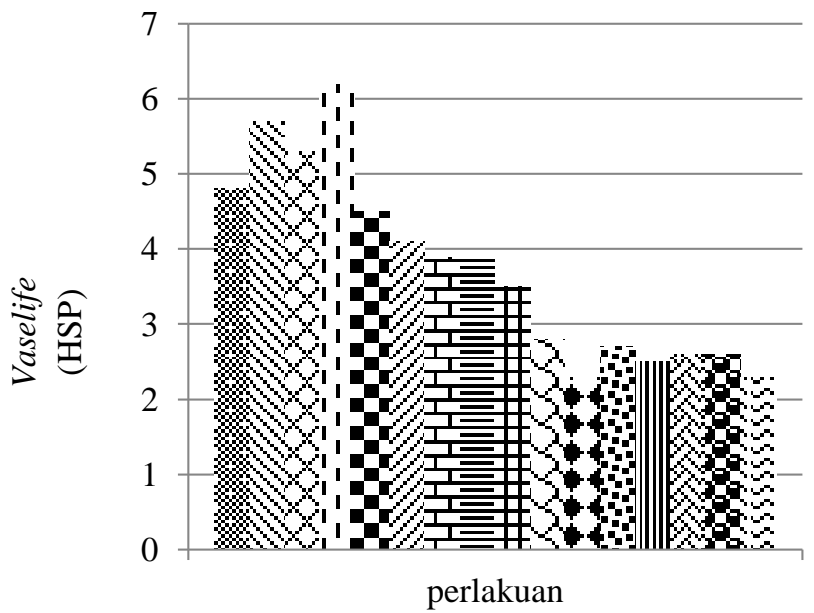

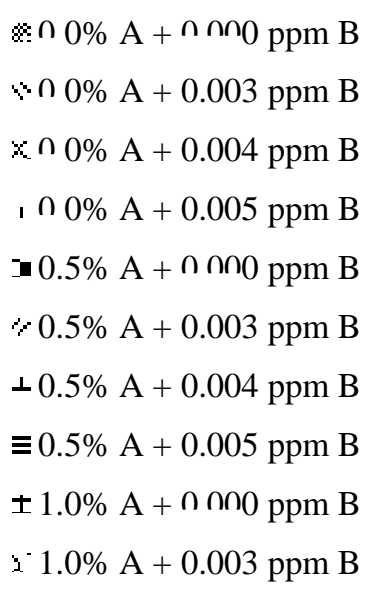

Gambar 1. Rata-rata vase life bunga potong Heliconia 'Sexy Pink' pada berbagai konsentrasi disinfektan dan 1-MCP. A: disinfektan. B: 1-MCP.

Vase life yang ditentukan berdasarkan perubahan $30 \%$ dari seluruh braktea menghitam (Ditflorikultura, 2006), tidak sama dengan peubah uji hedonik yang dilakukan oleh panelis. Perbedaan yang nyata dapat dilihat pada perlakuan dengan konsentrasi $0.0 \%$ disinfektan yang ditambah dengan berbagai konsentrasi 1-MCP. Pada vase life yang ditentukan oleh menghitamnya braktea, perlakuan $0 \%$ disinfektan yang ditambah dengan 0 ppm 1-MCP bertahan hingga 4.80 hari sedangkan pada uji hedonik panelis masih menyukai hingga 8 hari (Tabel 5).

Tabel 5. Pengaruh aplikasi disinfektan dan 1-MCP terhadap uji hedonik bunga potong Heliconia 'Sexy Pink'

\begin{tabular}{cccccc}
\hline \multirow{2}{*}{ Perlakuan } & \multicolumn{5}{c}{ Uji Hedonik } \\
\cline { 2 - 6 } & 0 HSP & 2 HSP & 4 HSP & 6 HSP & 8 HSP \\
\hline $0.0 \% \mathrm{~A}+0.000$ ppm B & 4 & 4 & 3 & 3 & 3 \\
$0.0 \% \mathrm{~A}+0.003$ ppm B & 5 & 4 & 4 & 3 & 3 \\
$0.0 \% \mathrm{~A}+0.004$ ppm B & 5 & 4 & 4 & 3 & 3 \\
$0.0 \% \mathrm{~A}+0.005$ ppm B & 5 & 4 & 4 & 3 & 3 \\
$0.5 \% \mathrm{~A}+0.000$ ppm B & 4 & 4 & 3 & 2 & - \\
$0.5 \% \mathrm{~A}+0.003$ ppm B & 4 & 3 & 2 & - & - \\
$0.5 \% \mathrm{~A}+0.004$ ppm B & 4 & 3 & 3 & - & - \\
$0.5 \% \mathrm{~A}+0.005$ ppm B & 4 & 3 & 3 & - & - \\
$1.0 \% \mathrm{~A}+0.000$ ppm B & 4 & 3 & 2 & - & - \\
$1.0 \% \mathrm{~A}+0.003$ ppm B & 4 & 3 & 2 & - & - \\
$1.0 \% \mathrm{~A}+0.004$ ppm B & 4 & 2 & - & - & - \\
$1.0 \% \mathrm{~A}+0.005$ ppm B & 4 & 3 & - & - & - \\
$1.5 \% \mathrm{~A}+0.000$ ppm B & 4 & 3 & - & - & - \\
$1.5 \% \mathrm{~A}+0.003$ ppm B & 4 & 2 & - & - & - \\
$1.5 \% \mathrm{~A}+0.004$ ppm B & 4 & 3 & - & - & - \\
$1.5 \% \mathrm{~A}+0.005$ ppm B & 4 & 3 & - & - & - \\
\hline
\end{tabular}

Keterangan: A: disinfektan; B: 1-MCP; - : pengamatan tidak dilakukan karena kriteria vase life telah terlewati; 1: sangat tidak suka; 2: tidak suka; 3: biasa; 4: suka; 5: sangat suka.

Faktor tunggal 1-MCP dengan konsentrasi tertinggi yaitu $0.005 \mathrm{ppm}$ dapat mempertahankan vase life selama 6.20 hari berdasarkan peubah $30 \%$ dari jumlah braktea menghitam, sedangkan panelis masih menyukai bunga potong Heliconia 'Sexy Pink' pada percobaan ini hingga 8 hari. Konsentrasi 0.003 ppm dan konsentrasi 0.004 ppm 1-MCP juga 
mengalami perbedaan antara peubah berdasarkan 30\% dari jumlah braktea menghitam dengan peubah uji hedonik. Vase life berdasarkan $30 \%$ braktea menghitam bertahan selama 5.70 hari dan 5.30 hari sedangkan berdasarkan uji hedonik masingmasing dapat bertahan hingga 8 hari. Hal tersebut terjadi karena pada peubah uji hedonik panelis menilai bunga potong Heliconia 'Sexy Pink' secara visual dengan tidak memperhitungkan jumlah braktea baru mekar yang menyebabkan jumlah braktea menghitam semakin sedikit terlihat. Berdasarkan peubah $30 \%$ dari seluruh braktea menghitam, munculnya braktea baru pada saat pengamatan tidak masuk kedalam perhitungan, sehingga vase life bunga potong Heliconia 'Sexy Pink' berdasarkan peubah $30 \%$ dari seluruh braktea menghitam tidak dapat dijadikan sebagai acuan karena panelis masih menyukai bunga potong hingga melewati kriteria 30\% dari seluruh braktea menghitam (Tabel 5).

Kriteria vase life $30 \%$ dari seluruh braktea menghitam berdasarkan standar Direktorat Budidaya Tanaman Hias untuk Standar Prosedur Operasional Zingiberaceae kurang tepat jika diterapkan pada bunga potong Heliconia 'Sexy Pink'. Braktea bunga potong dari famili Zingiberaceae pada saat dipanen sudah mekar semua sehingga pada saat penelitian berlangsung tidak ada braktea baru yang mekar. Braktea pada bunga potong Heliconia 'Sexy Pink' pada saat panen belum seluruhnya mekar, sehingga pada saat penelitian berlangsung terdapat penambahan jumlah braktea yang mekar. Oleh karena itu diperlukan pengembangan standar operasional untuk Heliconia 'Sexy Pink' untuk menentukan vaselife. Dari penelitian ini, peubah uji hedonik lebih direkomendasikan untuk menunjukkan vase life bunga potong Heliconia 'Sexy Pink'.

\section{KESIMPULAN}

Konsentrasi 1-MCP yang optimum untuk mempertahankan vase life bunga potong Heliconia 'Sexy Pink' berdasarkan peubah $30 \%$ braktea menghitam adalah 0.005 ppm; konsentrasi ini dapat memperpanjang masa segar bunga selama 6.20 hari. Vase life bunga potong Heliconia 'Sexy Pink' dengan kombinasi perlakukan tanpa disinfektan dan konsentrasi 1-MCP 0-0.005 ppm berdasarkan uji hedonik masih disukai panelis hingga 8 hari. Kriteria uji hedonik lebih direkomendasikan untuk menunjukkan vase life bunga potong Heliconia 'Sexy Pink'. Penambahan disinfektan tidak disarankan untuk mempertahankan vase life bunga potong Heliconia 'Sexy Pink', diduga karena konsentrasi yang diaplikasikan pada percobaan terlalu tinggi atau bunga potong Heliconia 'Sexy Pink' sensitive terhadap aplikasi bahan aktif disinfektan.

\section{DAFTAR PUSTAKA}

Abadi, D.H., B. Kaviani, S.S. Hoor, A.M. Torkavshvand, R. Zarei. 2009. Quality Management of Cut Carnation 'Tempo' with 1-MCP. Afr. J. Biotechnol. 8(20): 5351-5357.

Amiarsi, D., P.K. Utami. 2011. Peranan Larutan Pengawet terhadap Mutu Bunga Potong Alpinia Selama Peragaan. J. Hort. 21(2): 185-190.

Astuti. 1993. Kiat memperpanjang masa segar bunga potong. Balai Informasi Pertanian. Agro Informasi, Jakarta. 2: 18-19.

Bhattacharjee, S.K., L.C. De. 2005. Postharvest Technology of Flower and Ornamental Plants. Pointer Publisher. Jaipur. Rajasthan. India. 440.

Bigot, M. 2011. 'Sexy Pink'Heliconia 'Sexy Pink'. Waktu pembaharuan. http://www. sierraflowerfinder.com. [05 Oktober 2014].

Reid, M.S., F.G. Çelikel. 2008. Use of 1Methylcyclopropene in Ornamentals: Carnations as a Model System for Understanding Mode of Action. HortScience 43 (1): 95-98.

[Ditflorikultura] Direktorat Budidaya Tanaman Hias. 2006. Standar Prosedur Operasional Zingiberacea. [14 Mei 2015]. http://florikultura.org/pedum/ SOP_Zingiberaceae.pdf 
Efendi, D. 2005. Rekayasa genetika untuk mengatasi masalah-masalah pasca panen. Bul. Agron. 33: 50-51.

Kartika, J.G., I. Salsabila. 2013. Aplikasi 1methylcyclopropene untuk meningkatkan vase life bunga potong Tapeinochilos anannaceae K. Schum. Buletin Agrohorti. 1(4): 101-110.

Kartika, J.G., T. Adyantari. 2014. Aplikasi 1methylcyclopropene untuk meningkatkan vase life bunga potong Zingiber spectabile Griff. Silvana. J. Hort. Indonesia. 5(2): 128-136.

Lingga, L. 2007. Anthurium. PT Gramedia Pustaka Utama, Jakarta.

Macnish, A.J., K.L. Morris, A. de Theije, M.G.J. Mensink, H.A.M Boerrigter, M.S. Reid, C.Z. Jiang, E.J. Woltering. 2010. Sodium hypochlorite: A Promising Agent for Reducing Botrytis cinera Infection on Rose Flowers. Postharvest Biology and Technology. 58: 262-267.

Macnish, A.J., R.T. Leonard, T.A. Nell. 2008. Treatment with Chlorine dioxide extends the vase life of selected cut flowers. Postharvest Biology and Technology. $50:$ 197-207.

Mubarok, S. 2012. Kualitas bunga krisan potong "Yellow Fiji" sebagai respon dari aplikasi 1-Methylcyclopropene. J Agrivigor. 11(2): 244-250.

Pereira, F.R.A., R.M.M. Filho, L.S.S. Martins, A.V.V. Montarroyos, V. Loges. 2015.
Genetic Diversity and Morphological Characterization of Half-sib Families of Heliconia bihai L., H. chartacea Lane ex Barreiros, and $H$. wagneriana Peterson. Genetic and Molecular Research. 15(2): 1-9.

Qiuping, Z., X. Winshui. 2007. Effect of 1Methylcyclopropene and/or Chitosan Coating Treatments on Storage Life and Quality Maintenance of Indian Jujube Fruit. LWT. 40: 404-411.

Rimando, T.J. 2001. Ornamental Horticulture: A Little Giant in the Tropics. SEARCA, Filipines. 317 p.

Santoso, B.B. 2012. Penyimpanan komoditi hortikultura. 121-122. http://unram.ac.id. [23 Oktober 2014]:

Setyadjit, E. Sukasih, A.W. Permana. 2012. Aplikasi 1-MCP dapat memperpanjang umur segar komoditas hortikultura. Bul. Teknologi Pascapanen Pertanian. 8(1): 27-33.

Watkins, C.B. 2008. Overview of 1Methylcyclopropene Trials and Uses for Edible Horticultural Crops. HortScience. 43(1) : 86-94.

Wiryanto, K. 1993. Penanganan pascapanen bunga anggrek. Bul. Anggrek. 06:20.

Zencirkiran, M. 2010. Effects of 1-MCP (1 methylcyclopropene) and STS (silver thiosulphate) on The Vase Life of cut Freesia Flowers. Scientific Research and Essays. 5(17) : 2409-2412. 